Article

\title{
Transitory Courtyards as a Feature of Sustainable Urbanism on the East African Coast
}

\author{
Monika Baumanova (D)
}

check for updates

Citation: Baumanova, M. Transitory Courtyards as a Feature of Sustainable Urbanism on the East African Coast. Sustainability 2022, 14 , 1759. https://doi.org/10.3390/ su14031759

Academic Editor: J. Andres Coca-Stefaniak

Received: 5 January 2022

Accepted: 1 February 2022

Published: 3 February 2022

Publisher's Note: MDPI stays neutral with regard to jurisdictional claims in published maps and institutional affiliations.

Copyright: (c) 2022 by the author. Licensee MDPI, Basel, Switzerland. This article is an open access article distributed under the terms and conditions of the Creative Commons Attribution (CC BY) license (https:// creativecommons.org/licenses/by/ $4.0 /)$.
Centre for African Studies, Department of Middle Eastern Studies, University of West Bohemia, 30100 Pilsen, Czech Republic; monibau@kbs.zcu.cz

\begin{abstract}
The tropical urbanism of coastal East Africa has a thousand-year-long history, making it a recognized example of sustainable urbanism. Although economically dependent on trade, the precolonial Islamic towns of the so-called Swahili coast did not feature markets or other public buildings dedicated to mercantile activities before the European colonial involvement. In this regard, Swahili urban tradition differed from other tropical Islamic cities, such as in Morocco, Mali, Egypt or the Middle East, where markets fulfilled the role of social and economic hubs and, in terms of movement, major transitory/meeting spaces in the trading towns. Yet, the Swahili urban tradition thrived for centuries as a well-connected cosmopolitan type of tropical urbanism. As research has suggested, the public role of spaces associated with trade might have been fulfilled by houses. Using approaches of space syntax and network analysis, this article studies the morphology of the houses considering whether it could have been the courtyards that simulated the role of markets thanks to their transitory spatial configuration. The results are discussed reflecting on other models of houses with courtyards, especially the modern Swahili house appearing later in the colonial era when markets began to be established, and Islamic houses known from elsewhere.
\end{abstract}

Keywords: sustainable urbanism; precolonial; tropical urbanism; Swahili house; courtyard; trade; markets; transitory spaces; space syntax; Islamic house

\section{Introduction}

Within the last decade at least, the sustainability and resilience of urbanism have resonated as big themes across natural sciences and humanities alike. Given the current spread and intensity of urbanisation, the theme is highly relevant to present-day societies around the globe. Because of its complexity, analyses of urban sustainability require interdisciplinary approaches that consider a variety of evidence, as well as learning from historical experience. From the perspective of disciplines that deal with the past, such as archaeology and history, the sustainability of urban settlements is associated with time frames that significantly exceed the perspective of a few living generations. That is how the urban architectural heritage comprised of preserved buildings and urban layouts provides especially valuable insights into the long-term patterns and implications of various types of urban development. In comparison, the relatively short existence of today's post-industrial societies does not provide sufficient time depth to demonstrate whether, for example, the current model of European urbanism is sustainable environmentally and socially [1]. The notion whether it should be exported to other regions such as the tropics is hence brought to question by the arguments and accumulating evidence that it may not be. In this context, the studies of the past trajectories of urbanism in the tropics offer valuable perspectives on alternative indigenous models of urbanism, exemplified by the clustered cities of West African Sahel, the self-governing city-states of the East African coast or the long tradition of the nucleated cities of the Indian Peninsula [2-4]. The present paper expands on this still underexplored theme in studies of urban sustainability by focusing on the indigenous urbanism of the East African coast and exploring its long tradition that flourished since the beginning of the second millennium $\mathrm{CE}$. 
In the long-term perspective, one aspect of sustainable urbanism is a socio-spatial balance that withstands the test of time with the capacity to successfully deal with change. In the tropics, which are challenging in terms of urban economy, social themes or environmental conditions, the past teaches us that although change is constant, certain long-term patterns have characterised urban morphologies and traditions in the individual regions [5]. The continuity of these principles in the past trajectories of urban development and their capacity to adapt may serve as a useful model of resilience [6]. In this regard, material evidence provides data useful for informing future development. One type of material evidence is urban morphology or layouts, which represents a testament of possible movement networks in an architecturally defined space. The importance of morphology as an aspect of urban sustainability anywhere is increasingly recognised $[7,8]$.

Many regions in the tropics where we find long traditions of urbanism became colonies between the 17th and 19th centuries CE, and as such the preserved heritage in today's living historical towns has been strongly altered by architectural development imposed by colonial administrations. Yet, somewhat contrary to the need to study the longer-term precolonial aspects of sustainability, architectural studies of tropical urbanism are still predominantly concerned with colonial urbanism and architecture [9]. The potentially valuable architectural data on the precolonial built environment from archaeological sites are yet to be fully integrated into tropical urban studies, especially in sub-Saharan Africa which has a long tradition of urban development [10]. However, it remains a rather understudied area, as case studies on precolonial urbanism have been drawn from Mesoamerica and from Mayan and Aztec cities [11].

In tropical Africa, trade has always been an important driver of urbanisation [12]. This has been the case especially in liminal areas, such as the coasts, regions along major rivers and lakes, and on the edges of the main ecological zones that were positioned on major trade routes, such as in West Africa and the trade on the Niger, with the tropical forest zone or across the Sahara [13,14], or in the well-known state of Great Zimbabwe in southern Africa [15]. Compared with other types of urbanism with different economies, merchant towns were characterised by a greater population density and sustained an increased flow of people, offering multiple opportunities for social and material transactions [16]. The coast of East Africa is an example of such a region, encompassing the present-day countries of Kenya, Tanzania and Mozambique as well as parts of Somalia and Madagascar (Figure 1). Known also as the Swahili coast, it was a hub of long-distance trade at least throughout the 2 nd millennium CE. The trade networks reached to inland Africa as well as around the rim of the Indian Ocean to the Middle East, India and China. The importance of trade is attested by archaeological evidence and to a lesser extent by the scarce written sources of the precolonial period such as descriptions of the famous traveller Ibn Battuta [17]. Thanks to the seasonality of the monsoons, the towns regularly hosted visiting merchants. Islam was adopted on the coast relatively early on in the 11th century, and its popularity may also be associated with social and economic advantages, such as providing enhanced access to the trade networks of the Islamic world, especially with the Middle East. However, this also later led to exaggerating the importance of Arab influences in shaping Swahili urbanism-a practice which continues to be presented on archaeological heritage sites according to the personal experience of the author-and by a common practice of the tourism industry to misleadingly promote towns such as Zanzibar, subjected to profound Arab influence and entirely transformed by Omani colonialism, as 'typical' of Swahili urban traditions [18]. By focusing on the comparison of the long tradition of precolonial architecture with the (post)colonial examples, this paper aims to identify the patterns in urban space that might have contributed to the sustainability of the Swahili towns. 


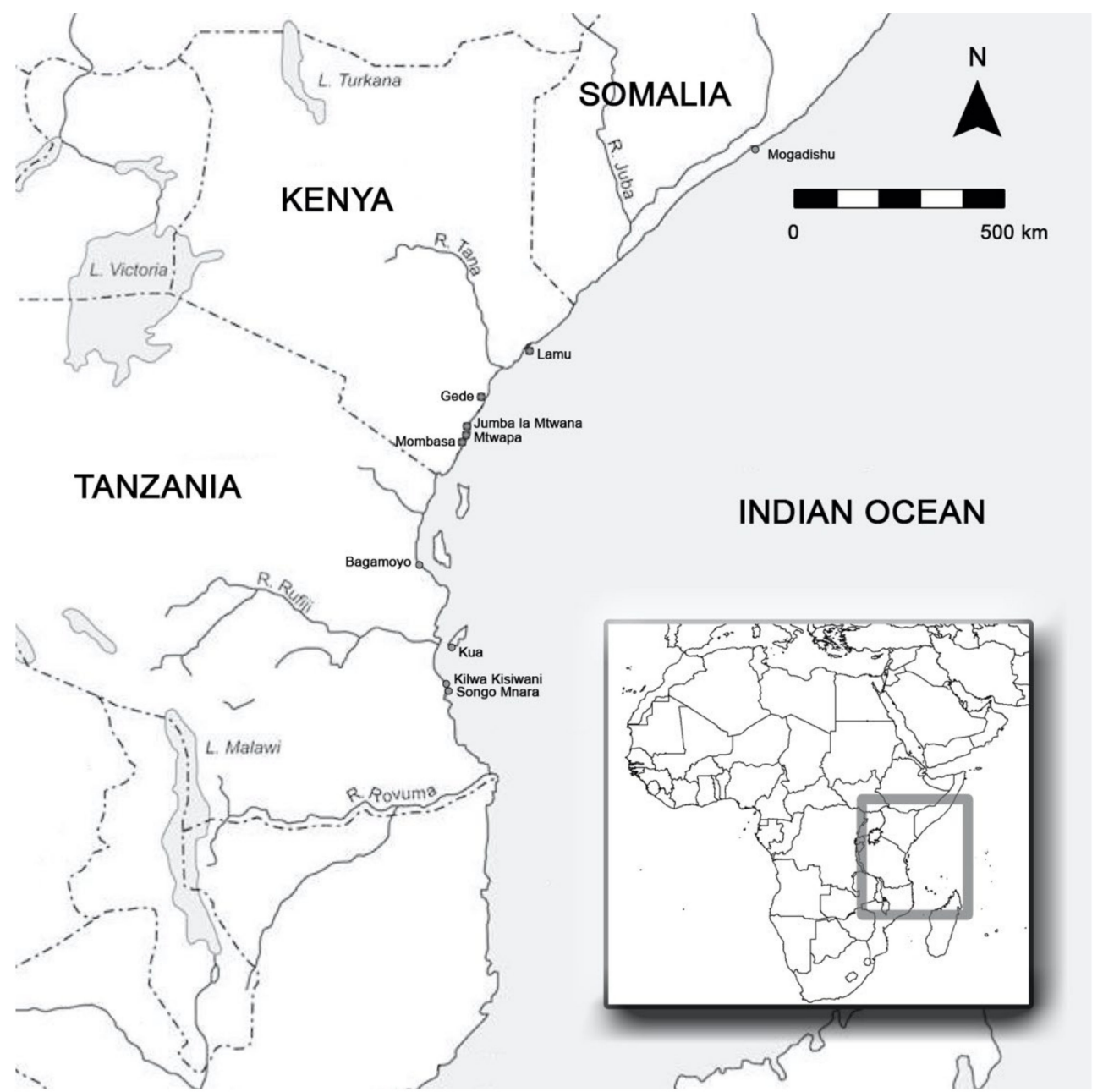

Figure 1. A map of the East African coast showing the location of the towns mentioned in the text.

There are significant differences in the layout and architectural character of the Swahili towns compared with the 'typical' examples of Islamic urbanism elsewhere in the tropics and subtropics. In Islamic towns, many of which are also merchant towns, the typical public buildings are represented by mosques, markets and the palace [19]. On the East African coast, no marketplaces have been identified on the sites of precolonial towns. Archaeologists now agree that, in the absence of markets, trade took place through houses [20]. It has been proposed that local trade used specific social mechanisms realised through a system of mediators as the major stakeholders in business transactions and who possessed special knowledge of the trading towns, had a network of contacts and adhered to a system of resident customers, which resulted in merchants setting up marketplaces within their houses [21]. However, the spatial mechanics of this proposed trade model are difficult to conclusively confirm on the basis of archaeological finds recovered from the precolonial houses. On the other hand, throughout the precolonial period, the Swahili stone house maintained a very standardised layout with a characteristic distribution of courtyard(s) and rooms. As the function of certain architectural features and buildings may be discernible from their morphology, it may be asked how the morphology of the houses reflected this practice suggested by previous research.

The Swahili towns started to feature markets only with the growing involvement of both Europeans and Arabs on the coast, who later administered the region as colonies. This may be exemplified by the town of Mombasa in Kenya, where colonial administrators built markets to rationalise commerce and centralise spaces of exchange [22] (p. 24). As the towns had functioned without dedicated markets for centuries, this change was clearly 
imposed on the spatial configuration by outsiders and, by extension, it can be expected that it also affected the social mechanisms of the Swahili towns. However, it did not arise from a potential lack of effectiveness of the established socio-spatial precolonial system without markets, which was sustainable for centuries. The houses adapted to the new configuration of the towns with their precolonial morphology also beginning to change-a trend which is even more apparent in the post-colonial period.

This paper addresses several issues that contribute to understanding the long-term experience of the urban form in the tropics and specifically in the Islamic context. With almost a millennium of indigenous development, it is apparent that precolonial Swahili urbanism was sustainable just as other types of more widespread Islamic urbanism that functioned on the principle that the market was the key economic centre and a hub of social life in the town, often occupying a central position [19]. The long-term adherence to the principle of Swahili towns without markets until this was changed by the colonial administration, confirms the social resilience of this practice. Furthermore, the role of places dedicated to mercantile activities in towns, where trade was of paramount importance, might have been taken up by house courtyards as suggested by archaeological and ethnographic research. The analysis presented here focuses on the spatial configuration of courtyards in the morphology of the houses, utilizing space syntax and network analysis as the main methodological framework in order to derive whether they could have substituted the role of markets within the houses. The sustainable placement of markets in other Islamic cities of tropical Africa and beyond hinged on their positioning on major crossroads, in central locations or on the edges of towns, such as in Timbuktu, Jenne Jenno, Cairo or Sijilmasa in western and northern Africa [23-25]. The goal of the analysis provided in this paper is to assess whether the positioning of courtyards in Swahili houses suggests they could have fulfilled the role of well-connected, busy spaces, that may be termed transitory, typical for markets elsewhere, and how this changed with the formal introduction of markets to Swahili colonial towns.

\section{Transitory Spaces in Precolonial Swahili Houses and Configurational Analysis}

Throughout the precolonial period when the Swahili towns were functioning as citystates along the entire 3000 kilometres of the coastline, there was a characteristic coherence in their architectural form and style. Some of this adherence to certain architectural features may be ascribed to the building material. The buildings on the coast were constructed of coral rag, which is an organic type of local limestone, and/or of wattle-and-daub, posing some limits on construction. As for the stone buildings, their layout is still preserved on hundreds of archaeological sites and may be defined on the basis of architectural data. The dimensions of the stone house rooms were limited by the length of mangrove poles typically used for roofing to a maximum of 2.5 metres. The largest spaces within the houses were hence open-air courtyards, also known as stepped courts, because sometimes they were circumscribed by lines of one or multiple steps that could have been used as benches (Figure 2). These courtyards were usually located close to a house entrance.

On the other hand, the characteristic layout of the precolonial house and especially its configuration in terms of arrangement of rooms respective to one another may be considered as not limited by the construction prerequisites, and hence it could have been driven by custom and preference. There is a significant body of evidence that suggests that the layout of the house was socially meaningful and important. First and foremost, the adherence to a certain house layout is apparent from the 12th to 17th century at the largest sites on which multiple examples of houses are preserved, such as at Kilwa, Kua or Songo Mnara in Tanzania and Jumba la Mtwana, Mtwapa or Gede, in Kenya. The size of the stone houses may range from just a single room to palace complexes of about 50 rooms. On the large sites, we may find examples of all of these. The most common were houses with 4-5 rooms (Figure 3), which have also been identified as units integrated into the greater houses or palace complexes, giving them a nucleated layout and possibly also serving for the accommodation of visitors [26]. 


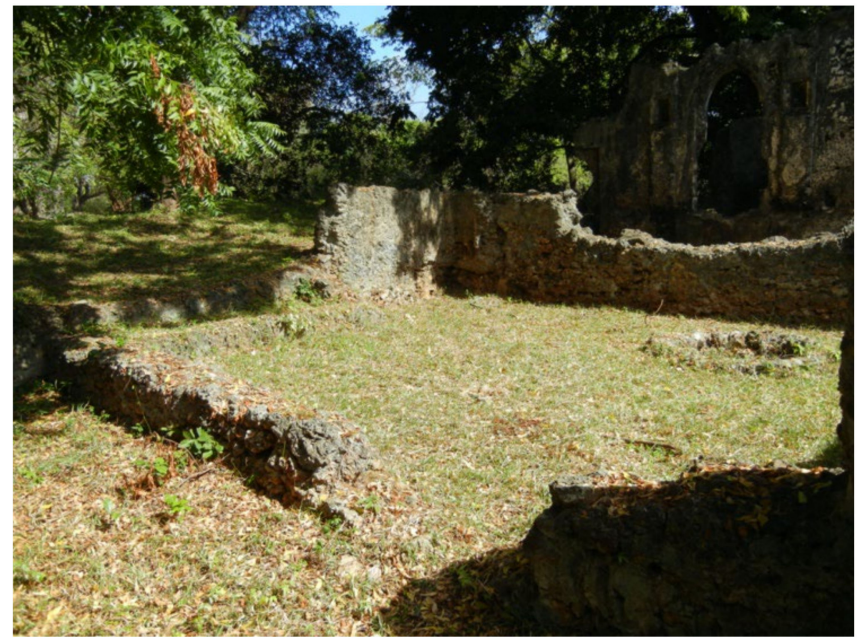

(a)

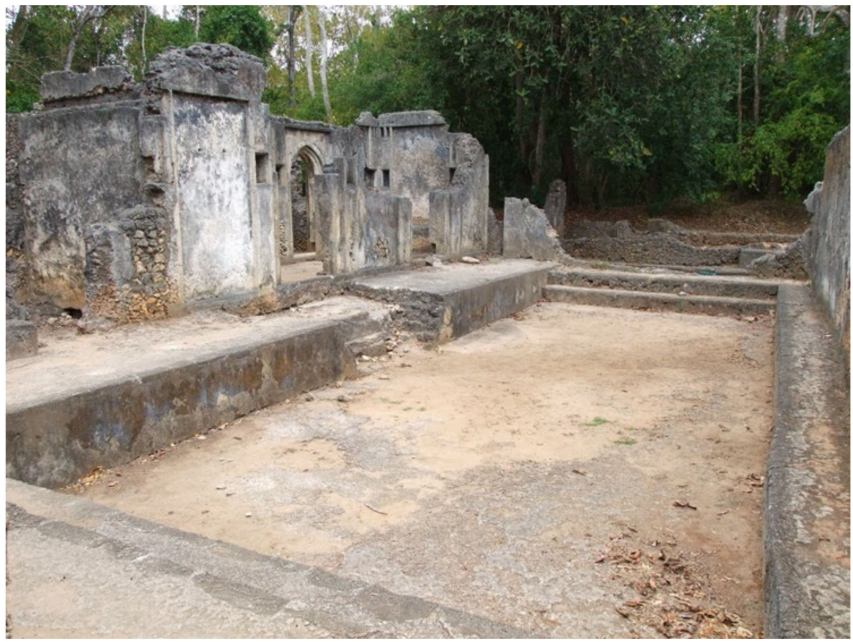

$(\mathbf{b})$

Figure 2. Example of the remains of precolonial Swahili houses. (a) A courtyard of a house on the site of Jumba la Mtwana (north of Mombasa), Kenya; (b) a stepped courtyard of a palace complex at the site of Gede (near Malindi), Kenya.

\section{0}

\section{밥}

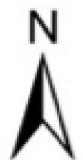

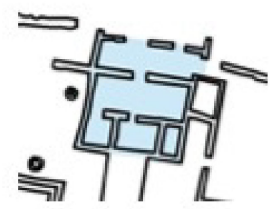

Figure 3. An example of the layout of a precolonial Swahili stone house of average size known as 'House of the Cowries' from the site of Gede, Kenya.

The house layout shown in Figure 3 and known from precolonial towns has continued to be used in some historical towns on the coast up to the present, such as Lamu in Kenya. The ethnographic study of this house layout showed that the configuration of the house was meaningful in two aspects: first, the rooms were arranged in a single line of gradated access with the front room(s) where visitors could be normally welcomed up to the back most private room(s) where access was possible only to the house residents, and second, that the arrangement of doorways allowed one to see from the front room to the very back room of the house where valuables might have been displayed in a niche wall [27]. However, the later houses which layouts resemble the precolonial house, and examples of which continue to be studied at Lamu or Mombasa, Kenya, often do not feature courtyards, or their courtyards are similar in size to a room and moved to the back of the house [28] rather than close to the entrance. Although the specific explanation of the later practices and meanings of the individual rooms cannot be simply projected on the precolonial past, it demonstrates both that the house layout may not be haphazard, and that the configuration of its rooms and courtyards evolved between the precolonial to postcolonial era even in historical towns that may appear 'traditional'.

In the precolonial period, the widely represented house layout may have carried important social connotations. It has been argued that the front, i.e., the outer rooms and courtyards, were decorative and functioned as a guarantee on trade and were probably used for hospitality [29] (p. 165). Early historical evidence contributes to this picture with more detail. The writings of Ibn Battuta, who was describing Mogadishu, Somalia, mention people sitting on benches directly in front of the houses or inside by the open doors, eating together and discussing business [30] (p. 36). Similarly, in early colonial Bagamoyo, 
Tanzania, the front doors of houses were usually left open during the day to create a link between outside space and the inside of the houses [31] (p. 124). Piecing together all of this evidence suggests that the front spaces of precolonial houses were characterised as a social space, open to the outside visually and physically and accessible both to visitors and house residents. It served as a buffer zone and transitory space between public and residential life.

Considering the transitory spaces as a concept, this term has incorporated various definitions. Such spaces have been described as unplanned and sometimes temporary, fulfilling multiple needs at the same time [32,33]. Elsewhere, they have been associated with migrant communities and peri-urban spaces [34]. In this article, transitory spaces are also defined on the basis of movement, with more accent on following the principles of socio-spatial networks [35]. In this vein, transitory spaces in urban layout may be identified as such that attract or facilitate a lot of movement, relative to others. Speaking in relative terms, spaces with a transitory function are located close to crossroads and on squares and entrances offering movement choice, as opposed to terminal spaces which may be identified near the path ends [36,37]. These are the same spaces, where in historical Islamic towns, markets are located centrally on major squares or on the edges of towns where major roads enter the urban network, as identified for e.g., in Timbuktu of Mali, Sijilmasa in Morocco or Islamic Palermo in medieval Sicily [23,24,38]. Major transitory spaces cannot be identified on sites of precolonial Swahili towns for two reasons. First, there is not a single site where the street network is preserved, and second, the incomplete preservation of perishable structures does not allow to reliably identify a void on a surface plan with an open space. Therefore, it cannot be assessed whether, when the colonial markets were established, they were placed at pre-existent transitory locations or whether they redefined the urban network.

On the other hand, the concept of transitory spaces may be used to analyse the abovediscussed theories that trade in precolonial Swahili towns took place within houses. All complex built structures that comprise multiple enclosed units or rooms also feature both transitory and terminal spaces, similar to urban layouts. If a building is imagined as a network of rooms within a larger urban network, then terminal spaces are positioned at the back of the house at the dead end of movement paths, while transitory spaces facilitate the flow of potential movement and as such they are well-connected, carrying movement to and from a building. The classification of transitory and terminal spaces may be understood as an alternative to the more frequently discussed dichotomy of private and public space within a house, which, following Vom Bruck's argument, refers to categories of interaction [39]. The classification referring to movement may also relate to interaction, but more importantly, it has a configurational function, which may reflect the movement and use dynamics.

This paper analyses the configuration of the average-sized precolonial stone houses on the Swahili coast, to the extent they may be considered typologically similar. The specific placement of courtyards used throughout the precolonial period is analysed in order to derive how the courtyard could have simulated the role of the marketplace in other Islamic towns. The layout of the house and configuration of its rooms are subjected to analysis using space syntax.

\section{Methodology of the Analysis}

Space syntax was developed as an approach to analyse the configurational mechanics and the relative privacy of certain spaces in a complex system, based on its connectivity to all other spaces. It was developed in the 1980s by Hillier and Hanson [40] and further elaborated in the 1990s [37]. This tool originating in the field of theoretical architecture may also be used in the context of individual buildings, where the complexity of the spatial layout of individual rooms/spaces is represented as a more readily intelligible graph. In the graph, the indoor spaces are distributed as nodes/points in levels of access, arranged for example from the entrance to the back room. Hence, space syntax addresses 
the shortcomings of traditional archaeological and architectural approaches that tend to present normative views of the built environment, lacking in analytical content. It reflects the perspective that the configuration of a built environment may be understood as a movement economy, recognising that even organically developed towns and buildings have an inherent structure [37]. Its principles are complemented by network analysis, which interprets the interlinked system of nodes in terms of connectivity as transitory and terminal spaces [35,36]. In an African context, both methodologies have been successfully used for analysis of palace complexes of sub-Saharan Africa, e.g., in the kingdom of Dahomey in West coastal Africa [41] and at Gede on the Swahili coast [42].

The houses selected for analysis are taken from sites that represent some of the largest precolonial towns and cover the period from the 8th to the 18th century, although most of the structures analysed here date from the 14th to 16th centuries, directly preceding the era of the European colonisation on the coast. The analysed houses are all parts of house blocks, in which they share one or more walls forming a complex built environment. The spatial context of these stone houses facilitates an opportunity to understand them in a complex urban setting (Table 1). As it has been argued by previous research on the size of houses along the coast, the houses with one entrance have on average 5 rooms, may have up to 7 but not more than 10 , while structures with 10 or more rooms tend to have multiple entrances and also multiple courtyards [26] (p. 85). There were also very small houses that did not feature a courtyard. The average-sized stone houses of 4-5 rooms, which are also the most common, are the focus of this analysis. In some cases, the state of preservation of parts of these blocks is incomplete, so there is some level of uncertainty discussed in relevant places in the analysis.

Table 1. A table showing the case study sites with period of occupation and approximate number of houses in the discussed house blocks.

\begin{tabular}{ccc}
\hline Town & Period & Approximate No. of Houses \\
\hline Gede (Kenya) & 8th-17th century & House block-11 houses \\
Jumba la Mtwana (Kenya) & 14th-15th century & House block-5 houses \\
Kilwa Kisiwani (Tanzania) & 9th-18th century & Great House-4 houses \\
\hline
\end{tabular}

\section{The Analysis and Results}

\subsection{The Configuration of the House Courtyards}

At the site of Gede, there is a house block comprised of approximately 11 houses. The layout of the so-called House of the Scissors, which got its name after a specific archaeological find, represents a very similar layout to another house from the same block shown in Figure 3 and the rest of the house units. The configuration of its rooms and position of the courtyard may be transcribed in a space syntax graph shown in Figure 4 . This shows that the courtyard was located close to the entrance, although it is unclear whether it was the first or second room beyond a small antechamber.

At Kilwa, another precolonial town in what is today Tanzania, the cluster of houses known as the Great House in fact comprises at least 4 houses, which were set close together [43]. In this case, the preservation of their configuration allows a more detailed consideration of the very limited possibilities of movement flow that the morphology of the houses offered, as represented in Figure 5 along with the space syntax analysis. 

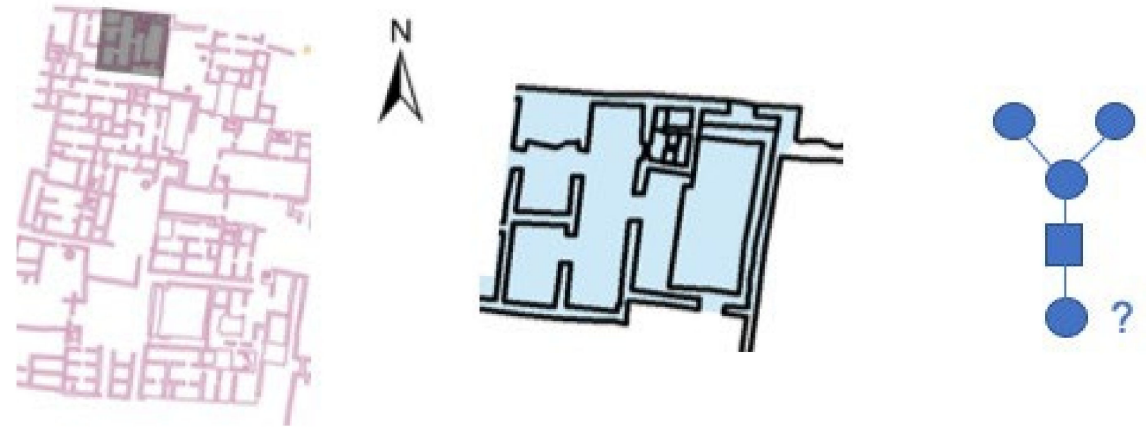

Figure 4. The so-called "House of the Scissors" from the House Block (shown on the left) at Gede, Kenya. The graph shows the space syntax transcription of the house configuration. Square represents the courtyard and circles represent rooms.
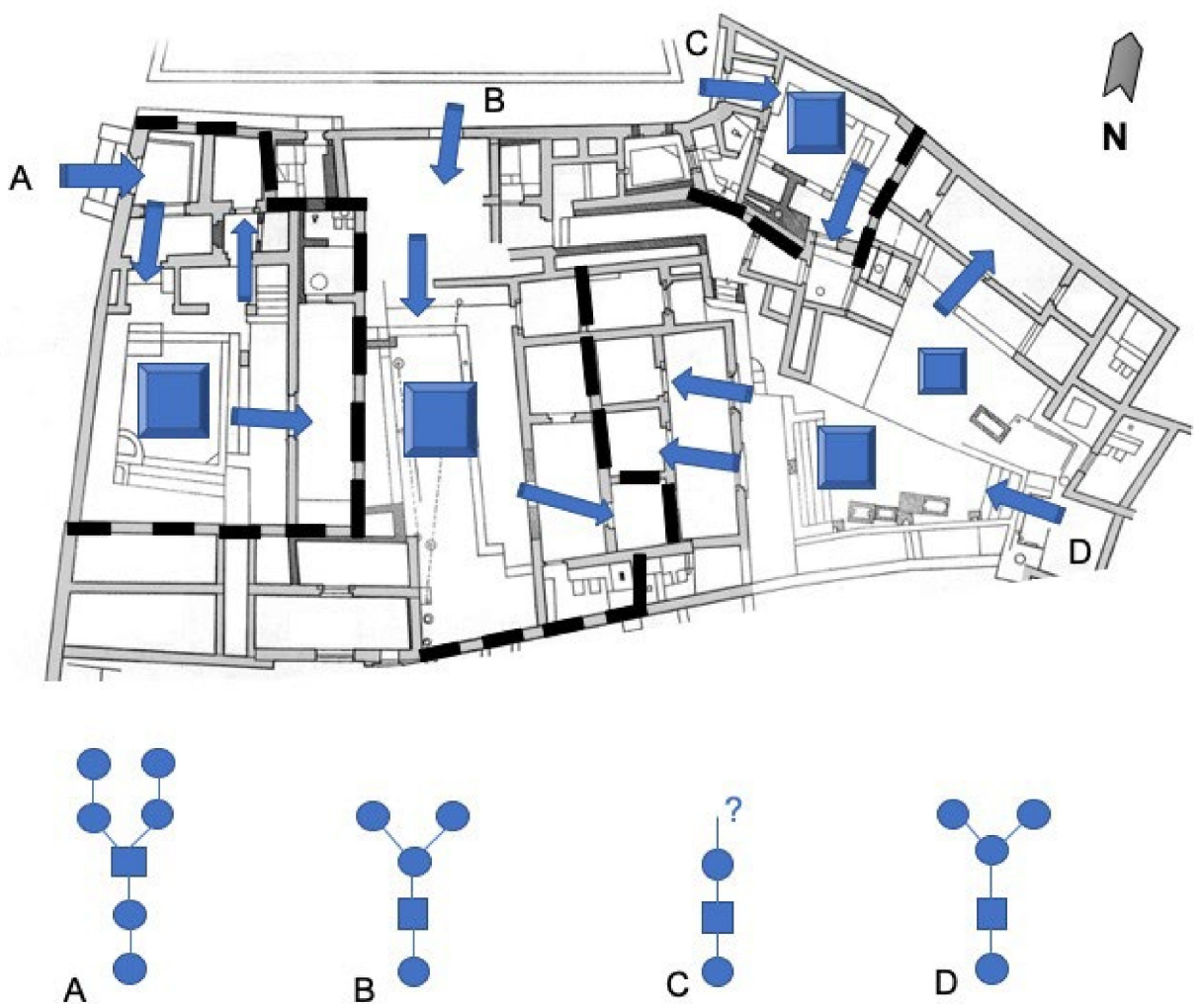

Figure 5. 'The Great House of Kilwa' actually comprised of at least 4 houses (as highlighted by the thick black outlines and letters A-D) based on excavation plans [43]. The arrows show the direction of movement promoted by the house configuration. Squares signify courtyards. The house labelled as $C$ might have had an upper storey, the layout of which is unknown.

At the site of Jumba la Mtwana in Kenya, a cluster of 5 or 6 houses also accentuates the importance of courtyards. The so-called House of Many Doors in fact consists of multiple house units very similar in layout. The arrangement of one of the house units is shown in Figure 6, where a courtyard is also positioned by the entrance, and only beyond it there are diverging movement paths-a very short one and a long one to the house proper. 

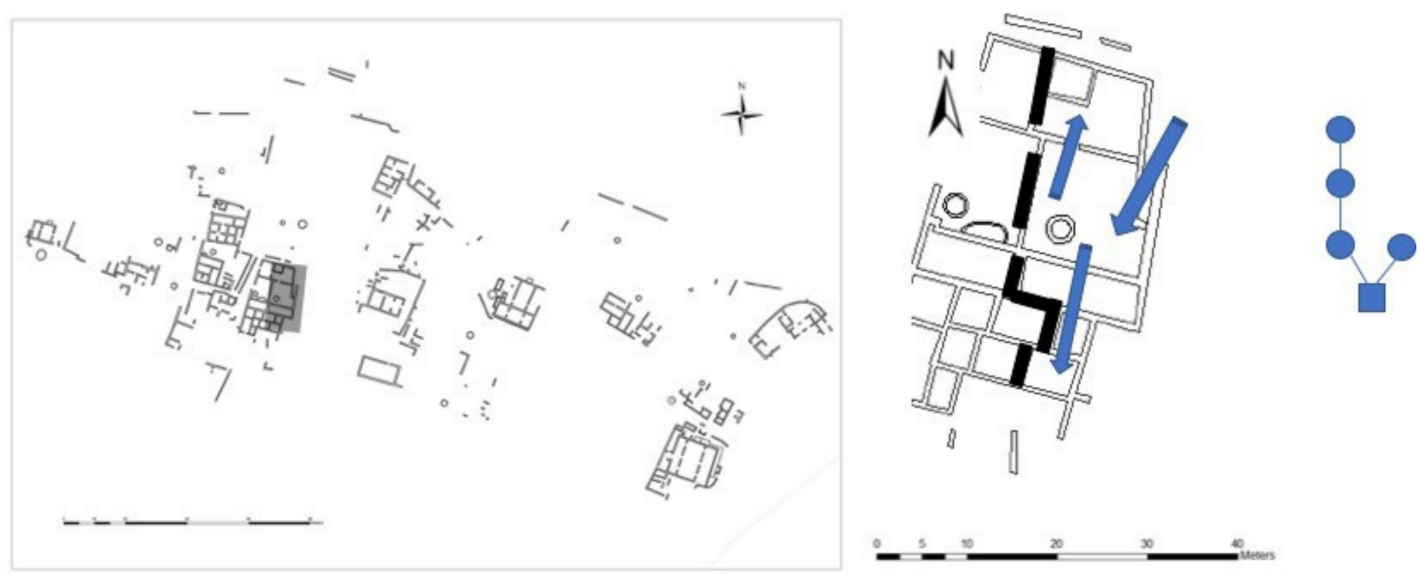

Figure 6. The layout and space syntax graphs of a house unit from the block known as 'House of Many Doors' in the precolonial town of Jumba la Mtwana, Kenya. The location of the house is highlighted on the town plan on the left.

\subsection{Main Outcomes}

On the basis of the presented analysis, several patterns may be identified in the spatial configuration of houses preserved in the precolonial house blocks. These may be summarized as follows:

- From the entrance, there is a strong preference for the courtyard to be positioned as the second room in line of access. Sometimes it may be the first or the third;

- The observed configurations suggest that the precolonial houses were configured as relatively deep structures, with 5 rooms arranged on 4 levels of depth. The spaces within the house are ordered in a single line, accessible one after another, and this linear configuration usually branches out on the last level of rooms;

- The layout of the houses is such that only the entry to the first room beyond the doorway opens to a view of the courtyard, and a view from the courtyard then opens more sightlines to the rest of the house.

These observed patterns suggest that in precolonial houses, a number of rooms were positioned as terminal spaces, distant from the entrance from which they were separated by the courtyard. On the other hand, the courtyard was the ultimate transitory space and according to network principles channelled most movement. As a major crossroads from which both the exterior space and interior rooms were accessible, it was ideally positioned to fulfil the role of social space and possibly the space for trade transactions, missing from the urban layout.

This may be compared with other models of courtyard positioning which have been identified in later Swahili towns and in other Islamic urban traditions of the (sub)tropics, e.g., in West or North Africa and the Middle East [28,44-46] shown in Figure 7. The model of the modern Swahili houses and the 'typical' Islamic courtyard house both show a branched, non-linear layout. The later Swahili house began to be built gradually under the influence of colonial development, which included the introduction of markets to the urban space. The courtyard is located at the back of the house and becomes a terminal space in the configurational network; the house also includes a central corridor. In the latter case of the Islamic courtyard house, rooms are positioned around a central courtyard. In this model, the structure is shallow and the courtyard is located at the heart of the house; as such, it does not provide a buffer zone from the residential space but is part of it. 

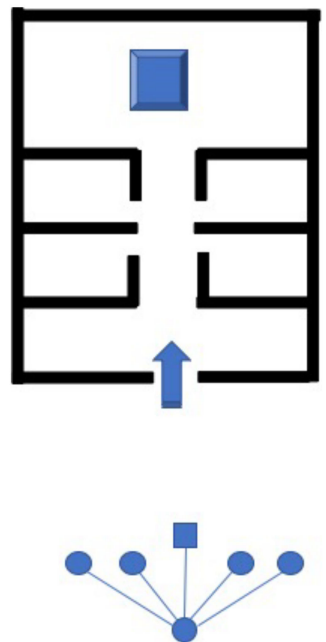

(a)
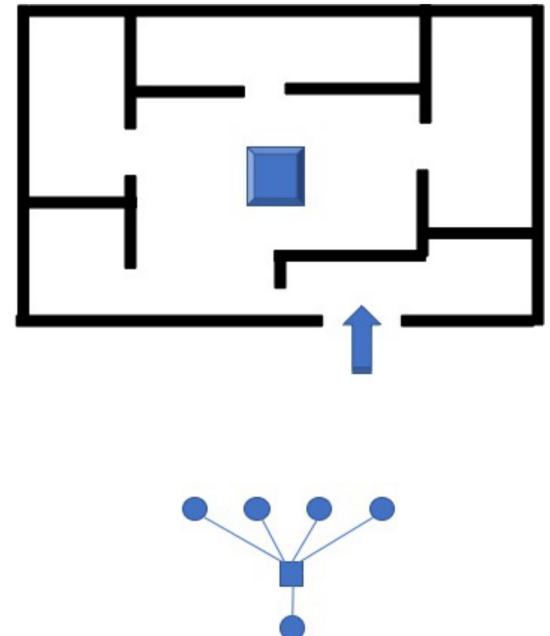

(b)

Figure 7. Other models of courtyard houses. (a) layout and space syntax graph of a later/modern house on the Swahili coast; (b) layout and space syntax graph of an Islamic courtyard house recorded for e.g., in the Middle East or West Africa.

\section{Discussion}

As it has been discussed in this paper, past research suggested that in the absence of markets or other buildings dedicated to mercantile activities in the precolonial Swahili towns, trade might have been realised through houses. The layout of the 'traditional' Swahili house has been described as a structure where individual rooms are arranged in a linear sequence with great potential for privacy in the back rooms $[27,47,48]$. The analysis presented here focused on the courtyard in order to derive whether its position in the configuration of the house suggests that this particular space might have substituted the role of markets. The results show that the placement of courtyards within the precolonial houses facilitated their use as social, transitory spaces and supports the notion that the precolonial courtyards were transitory spaces. As such, they were ideally positioned to serve activities associated with trade negotiations, which included hosting the visiting traders and facilitating business meetings.

In trading towns, trade activities must have been situated at specific places, because, among other reasons, trade links and goods were associated with the control of power. In this setting, the precolonial Swahili model was sustainable, as attested by the longevity of this urban tradition, interrupted only by the colonial era. The same longevity in the layout of the houses shows that their configuration might have helped to strike a balance with the urban setting. Hence, the transitory courtyard played a crucial role in the long-term social sustainability of urbanism on the coast of tropical East Africa.

Later in the colonial period, the urban context of trade gradually changed when markets were introduced to the coastal towns under Omani and European influence. Within the house, the configuration of the courtyard also changed. It was moved towards the back of the house and became much smaller, which might have reflected the altered configuration of the town as a whole. Houses with this layout have been documented as the most common in the 1980s survey of architectural heritage in Lamu [28], and also continue to be used in Mombasa, Kenya. This process shows that although the layout, i.e., the external shape and appearance, of the Swahili house might not have changed significantly over time, the internal configuration of the house did. The need for house courtyards to have a transitory character was diminished and virtually disappeared in the later towns with markets. Hence, the process when trade opportunities were being channelled out of Swahili hands [18] may have had a spatial reflection.

The presented results, namely that in the precolonial period courtyards as parts of residential buildings fulfilled a role usually associated with public space, potentially have 
implications for understanding the role of public and residential space in general. Even in the absence of evidence on complete urban morphology, it may be stated that there was possibly a link between the layout of the houses and the exterior urban setting. This has connotations for sustainability, as the spatial mechanics of both types of constructed space are often considered separately, while in fact they may be entangled and interlinked. This means that in disentangling the functional properties of urban traditions, analysing the configuration of indoor and outdoor spaces as part of the urban network may carry underlying patterns not discernible on the basis of the normative categories of building types. In this case, the precolonial Swahili towns in tropical East Africa represent an alternative model of socially sustainable Islamic towns to other regions.

Future in-depth research into the chronology of the houses and their transformation would bring new insights into this relationship. Excavation on sites where the archaeological deposits have not been lifted, and analysis of placement and form of architectural features such as benches and wells may shed more light on the potential location of social hotspots in the context of courtyards. A detailed study of the transformation of the town morphology would also facilitate a better understanding of how colonial development altered the spatial relationships in the towns. The disciplinary boundaries between the study of the precolonial, colonial and postcolonial periods need to be bridged in order to view and assess the impact of change on the sustainability of urban morphologies. Especially the past, in the context of precolonial tropical regions, traditions need to be paid significant attention as they may represent long-lived models of sustainable urbanism. Positively affecting the future development of cities in tropical Africa and beyond largely depends on an in-depth understanding of the long-term causalities of change and socio-spatial configurations.

Funding: This research and APC were funded by the GRANT AGENCY OF THE CZECH REPUBLIC (Czech Science Foundation), grant number 20-02725Y.

Institutional Review Board Statement: Not applicable.

Informed Consent Statement: Not applicable.

Data Availability Statement: Not applicable.

Acknowledgments: I am grateful to the team of surveyors of the Zamani Project headed by Heinz Ruther, University of Cape Town, for their long-term cooperation in surveying and documenting some of the towns discussed in this paper.

Conflicts of Interest: The author declares no conflict of interest.

\section{References}

1. Curtis, D.R. Coping with Crisis: The Resilience and Vulnerability of Pre-Industrial Settlements; Ashgate: Burlington, VT, USA, 2014.

2. Yoffee, N. (Ed.) Early Cities in Comparative Perspective 4000 BCE-1200 CE; Cambridge University Press: Cambridge, UK, 2014; Volume 3.

3. Wright, R.P. The Ancient Indus: Urbanism, Economy, and Society; Cambridge University Press: New York, NY, USA, 2010.

4. Fleisher, J.B.; LaViolette, A.J. The archaeology of sub-Saharan urbanism: Cities and their countrysides. In African Archaeology: A Critical Introduction; Stahl, A.B., Ed.; Blackwell Pub.: Malden, MA, USA, 2005; pp. 327-352.

5. Smith, M.L. (Ed.) The Social Construction of Ancient Cities; Smithsonian Institution Press: Washington, DC, USA, 2003.

6. Van Oers, R.; Roders, A.P. Historic cities as model of sustainability. J. Cult. Herit. Manag. Sustain. Dev. 2012, 2, 4-14. [CrossRef]

7. Maretto, M. Sustainable urbanism: The role of urban morphology. Urban Morphol. 2014, 18, 163-164.

8. Hermand, S.; Quesada, M.G. Rethinking the Impact of Urban Form in Sustainable Urban Planning Policy. Eur. J. Sustain. Dev. 2019, 8, 325-334. [CrossRef]

9. Chang, J.-H.; King, A.D. Towards a genealogy of tropical architecture: Historical fragments of power-knowledge, built environment and climate in the British colonial territories. Singap. J. Trop. Geogr. 2011, 32, 283-300. [CrossRef]

10. Sinclair, P. Urbanism. In The Swahili World; Wynne-Jones, S., LaViolette, A.J., Eds.; Routledge: London, UK, 2018 ; pp. 185-193.

11. Isendahl, C.; Smith, M.E. Sustainable agrarian urbanism: The low-density cities of the Mayas and Aztecs. Cities 2013, 31, 132-143. [CrossRef]

12. Sinclair, P. The Archaeology of African urbanism. In The Oxford Handbook of African Archaeology; Mitchell, P., Lane, P., Eds.; Oxford University Press: Oxford, UK, 2013; pp. 689-702. 
13. Holl, A.F.C. West African Early Towns: Archaeology of Households in Urban Landscapes; Museum of Anthropology, University of Michigan: Ann Arbor, MI, USA, 2006.

14. Levtzion, N.; Spaulding, J. Medieval West Africa: Views from Arab Scholars and Merchants; Markus Wiener Publishers: Princeton, NJ, USA, 2003.

15. Pikirayi, I. The Zimbabwe Culture: Origins and Decline of Southern Zambezian States; AltaMira Press: Walnut Creek, CA, USA, 2001.

16. Vernet, T. East African Travelers and Traders in the Indian Ocean: Swahili Ships, Swahili Mobilities ca. 1500-1800. In Trade, Circulation, and Flow in the Indian Ocean World; Pearson, M.N., Ed.; Palgrave Macmillan: New York, NY, 2015 ; pp. 167-202.

17. Freeman-Grenville, G.S.P. The East African Coast; Select Documents from the First to the Earlier Nineteenth Century; Clarendon Press: Oxford, UK, 1962.

18. Meier, P. Swahili Port Cities: The Architecture of Elsewhere; Indiana University Press: Bloomington, INDY, USA, 2016.

19. Eickelman, D.F. The Middle East: An Anthropological Approach; Prentice-Hall: Englewood Cliffs, NJ, USA, 1981.

20. Wynne-Jones, S. The public life of the Swahili stonehouse, 14th-15th centuries AD. J. Anthropol. Archaeol. 2013, 32, 759-773. [CrossRef]

21. Suzuki, H. Agency of Littoral Society: Reconsidering medieval Swahili port towns with written evidence. J. Indian Ocean Stud. 2018, 2, 73-86. [CrossRef]

22. Heathcott, J. Historic urban landscapes of the Swahili coast: New frameworks for conservation. In The Swahili Historic Urban Landscapes; Van Oers, R., Haraguchi, S., Eds.; UNESCO: Paris, France, 2013; pp. 20-39.

23. Baumanova, M.; Smejda, L.; Rüther, H. Pre-Colonial Origins of Urban Spaces in the West African Sahel: Street Networks, Trade, and Spatial Plurality. J. Urban Hist. 2019, 45, 500-519. [CrossRef]

24. Messier, R.A.; Miller, J.A. The Last Civilized Place: Sijilmasa and Its Saharan Destiny; University of Texas Press: Austin, TX, USA, 2015.

25. Garcin, J.-C. Le Caire et l'évolution urbaine des pays musulmans à l'époque médiévale. Ann. Islamologiques 1991, $25,289-304$.

26. Baumanova, M.; Smejda, L. Space as material culture: Residential stone buildings on the precolonial Swahili coast in a comparative perspective. S. Afr. Archaeol. Bull. 2018, 73, 82-92.

27. Donley, L. House power: Swahili space and symbolic markers. In Symbolic and Structural Archaeology; Hodder, I., Ed.; Cambridge University Press: Cambridge, UK, 1982; pp. 63-73.

28. Siravo, F.; Pulver, A. Planning Lamu: Conservation of an East African Seaport; National Museums of Kenya: Nairobi, Kenya, 1986.

29. Wynne-Jones, S. A Material Culture: Consumption and Materiality on the Coast of Precolonial East Africa; Oxford University Press: Oxford, UK, 2016.

30. Ali, O.H. Islam in the Indian Ocean World: A Brief History with Documents; Bedford/St. Martin's: Boston, MA, USA, 2016.

31. Fabian, S. Making Identity on the Swahili Coast: Urban Life, Community, and Belonging in Bagamoyo; Cambridge University Press: New York, NY, USA, 2019.

32. Banerjee, P.; Mallik, C.; Babu, N. Measuring and Mapping Transitory Spaces in India: A Case Study of Hyderabad City. Vision 2015, 18, 277-287. [CrossRef]

33. Ostertag, E. Transitory community hubs. City Anal. Urban Chang. Theory Action 2016, 20, 116-129. [CrossRef]

34. Elsheshtawy, Y. Transitory Sites: Mapping Dubai's 'Forgotten' Urban Spaces. Int. J. Urban Reg. Res. 2008, 32, 968-988. [CrossRef]

35. Brughmans, T.; Collar, A.; Coward, F.S. (Eds.) The Connected Past: Challenges to Network Studies in Archaeology and History; Oxford University Press: Oxford, UK, 2016.

36. Knappett, C. Networks in archaeology: Between scientific method and humanistic metaphor. In The Connected Past: Challenges to Network Studies in Archaeology and History; Brughmans, T., Collar, A., Coward, F.S., Eds.; Oxford University Press: Oxford, UK, 2016; pp. 21-33.

37. Hillier, B. Space is the Machine: A Configurational Theory of Architecture; Cambridge University Press: Cambridge, UK, 1999.

38. Nef, A. (Ed.) A Companion to Medieval Palermo: The History of a Mediterranean City from 600 to 1500; Brill: Leiden, The Netherlands, 2013.

39. Vom Bruck, G. A house turned inside out. J. Mater. Cult. 1997, 2, 139-172. [CrossRef]

40. Hillier, B.; Hanson, J. The Social Logic of Space; Cambridge University Press: Cambridge, UK, 1984.

41. Monroe, J.C. The Precolonial State in West Africa: Building Power in Dahomey; Cambridge University Press: Cambridge, UK, 2014.

42. Baumanova, M.; Smejda, L. Structural dynamics of spatial complexity at the 'Palace of Gede', Kenya. Azania Archaeol. Res. Afr. 2017, 52, 71-99. [CrossRef]

43. Chittick, H.N. Kilwa: An Islamic Trading City on the East African Coast; British Institute in Eastern Africa: Nairobi, Kenya, 1974.

44. Greenhalgh, M. Constantinople to Cordoba: Dismantling Ancient Architecture in the East, North Africa and Islamic Spain; Brill: Boston, MA, USA, 2012.

45. Bianca, S. Urban Form in the Arab World: Past and Present; VDF: Zurich, Switzerland, 2000.

46. Alananga, S. The Impact of Traditional House-type on Rental Values in Kinondoni Municipality Dar es Salaam Tanzania. Nord. J. Surv. Real Estate Res. 2017, 12, 7-37.

47. Fleisher, J. Situating the Swahili house. In Theory in Africa, Africa in Theory: Locating Meaning in Archaeology; Wynne-Jones, S., Fleisher, J.B., Eds.; Routledge: New York, NY, USA, 2015; pp. 72-88.

48. Garlake, P.S. Early Art and Architecture of Africa; Oxford University Press: Oxford, UK, 2002. 